\title{
Characterization of Post-Inflammatory Hyperpigmentation related to Acne by Reflectance Confocal Microscopy: Morphological and structural aspects
}

\author{
Caracterização da Hiperpigmentação Pós Inflamatória relacionada à acne por Microscopia \\ Confocal de Reflectância: Aspectos morfológicos e estruturais
}

\author{
Ana Paula M. Martini, Gabriela M. D. Costa, Patrícia M. B. G. Maia Campos \\ University of São Paulo, School of Pharmaceutical Sciences of Ribeirão Preto, Brazil \\ Email: pmcampos@usp.br
}

\begin{abstract}
Post-Inflammatory Hyperpigmentation (PIH) is a common pigmentary disorder in patients with pigmented skin. Histological and clinical exams have been used for the diagnosis of PIH and to determine the correct treatment. However, Reflectance Confocal Microscopy (RCM) has the potential to replace these methods since it is a noninvasive advanced technique and has a higher diagnostic accuracy than dermatoscopy. The aim of this study was to characterize PIH and correlate the main aspects observed by RCM with the macroscopic characteristics of acne-related PIH. Thus, 12 subjects with previously diagnosed acne and PIH were selected for the study. PIH was evaluated by RCM. The brightness of the basal cell layer, the dermal-epidermal junction (DEJ) thickness, and the depth of dermal papillae were quantified and the morphological and structural features of the DEJ were analyzed. The results showed an increase of epidermal pigmentation, a reduction of DEJ thickness, and no change in epidermal thickness. Melanophages were observed in the papillary dermis, as well as changes in the size and shape of dermal papillae. Finally, the study describes the characteristics of PIH and can help dermatologists to diagnose PIH with an innovative method that reduces the stress associated with a histological biopsy.
\end{abstract}

Keywords: Reflectance Confocal Microscopy, post-inflammatory hyperpigmentation, skin characterization, clinical study

\section{Resumo}

Hiperpigmentação Pós Inflamatória (HPI) é uma desordem pigmentar comum em pacientes com pele pigmentada. Exames histológicos e clínicos são utilizados para o diagnóstico de HPI e para determinar o tratamento correto. Entretanto, a Microscopia Confocal de Reflectância à laser (MCR) tem potencial para substituir esses métodos, pois é uma técnica avançada de imagem, não invasiva e possui maior precisão diagnóstica do que a dermatoscopia. $\mathrm{O}$ objetivo deste estudo foi caracterizar a HPI e correlacionar os principais aspectos observados por MCR às características macroscópicas da HPI relacionada à acne. Para tal, 12 participantes de pesquisa com diagnóstico prévio de acne e HPI foram selecionadas e avaliadas por MCR. O brilho da camada basal, a espessura da junção dermoepidérmica (JDE) e a profundidade das papilas dérmicas foram quantificados e as características morfológicas e estruturais da JDE foram analisadas. Os resultados mostraram aumento da pigmentação epidérmica, redução da espessura da JDE e espessura da epiderme. Melanófagos foram observados na derme papilar, assim como mudanças no tamanho e na forma das papilas dérmicas. Por fim, este estudo descreve as características da HPI a fim de auxiliar os dermatologistas no diagnóstico de PIH com um método inovador que reduz o estresse associado à biópsia histológica.

Palavras-Chave: Microscopia confocal de reflectância, hiperpigmentação pós inflamatória, caracterização da pele, estudo clínico 


\section{Introduction}

Post-inflammatory hyperpigmentation (PIH) is a very common consequence of acne often as bothersome or more so than acne itself (1). PIH has many psychological and cultural implications since the pigmentary changes can alter a patient's self-image (2). Since acne is as inflammatory process, it can initiate $\mathrm{PIH}$, which is an increase of cutaneous pigmentation associated with an inflammatory process (3). That occurs at higher frequency in Fitzpatrick skin types III-V (4), mainly affecting the cheeks and the mandibular area and lasting at least one year (1).

In PIH, there is either excess melanin production or an abnormal distribution of melanin pigment deposited in the epidermis and/or dermis (2). The epidermal hypermelanosis results from the increase of melanin synthesis stimulated by inflammatory mediators (such as interleukin-1a and endothelin-1 released from inflammatory cells) or reactive oxygen species, resulting in the deposition of pigment in the surrounding keratinocytes $(3,5,6)$, mainly in the dermal-epidermal junction (DEJ). In the upper dermis, when there is destruction of basal keratinocytes $(2,6)$ the melanin is phagocytozed by macrophages (melanophages) $(7,8)$, causing this lesion to be more persistent in some cases (2). The diagnosis of PIH is usually examined with the unaided eye and with the aid of a dermatoscope, but recent studies suggest that there are issues with consistent diagnosis of PIH (9).

In this context, Reflectance Confocal Microscopy (RCM), a non-invasive method, has the potential to replace these methods and to reduce the pain, time, and anxiety associated with a histological biopsy $(10,11)$. The use of RCM in dermatology has increased over the last few years (12), especially for the diagnosis of pigmentary lesions as melanin is the strongest endogenous contrast in the human skin (13). Considering that many lesions with different biologies may show similar features on dermatoscopy (14), RCM can significant reduce the chance of errors since this method has a higher specificity and diagnostic accuracy than dermatoscopy $(14,15)$.

Considering the inconsistency of some PIH diagnoses (9), the potential of RCM in reducing misdiagnosis $(14,15)$, and the lack of studies for the characterization of PIH using RCM, the aim of the present study was to characterize $\mathrm{PIH}$ and to correlate the main aspects observed by RCM with the macroscopic characteristics of acne-related PIH. This way, the understanding of the morphological characteristics of PIH is determinant to confirm the diagnosis, guide the development of effec-

\section{Introdução}

A Hiperpigmentação Pós-Inflamatória (HPI) é uma sequela muito comum da acne, muitas vezes tão incômoda ou mais do que a própria acne (1). A HPI tem muitas implicações psicológicas e culturais, uma vez que as alterações pigmentares podem alterar a autoimagem do paciente (2). Como a acne é um processo inflamatório, pode iniciar a HPI, que é um aumento da pigmentação cutânea associada a um processo inflamatório (3). Isso ocorre em maior frequência nas peles de Fitzpatrick tipo III-V (4), afetando principalmente as bochechas e a área mandibular e com duração de pelo menos um ano (1).

$\mathrm{Na} \mathrm{HPI}$, há excesso de produção de melanina ou distribuição anormal de pigmento de melanina depositado na epiderme e/ou derme (2). A hipermelanose epidérmica resulta do aumento da síntese de melanina estimulada por mediadores inflamatórios (como a interleucina-1a e a endotelina-1 liberados por células inflamatórias) ou espécies reativas de oxigênio, resultando na deposição de pigmento nos queratinócitos adjacentes $(3,5,6)$, principalmente na junção dermo-epidérmica (DEJ). Na derme superior, quando há destruição de queratinócitos basais $(2,6)$, a melanina é fagocitada por macrófagos (melanófagos) $(7,8)$, tornando essa lesão mais persistente em alguns casos (3). O diagnóstico de HPI é geralmente examinado a olho nu e com o auxílio de um dermatoscópio, mas estudos recentes sugerem que há problemas com o diagnóstico consistente de HPI (9).

Nesse contexto, a Microscopia Confocal de Reflectância (MCR), uma técnica não invasiva, tem o potencial de substituir esses métodos reduzindo a dor, o tempo e a ansiedade associados a uma biópsia histológica (10, 11). O uso da MCR na dermatologia tem aumentado nos últimos anos (12), principalmente para o diagnóstico de lesões pigmentares, uma vez que a melanina é o mais forte contraste endógeno na pele humana (13). Considerando que muitas lesões com diferentes biologias podem apresentar características semelhantes na dermatoscopia (14), a MCR pode reduzir significativamente a chance de erros, uma vez que esse método possui precisão diagnóstica e maior especificidade do que a dermatoscopia $(14,15)$.

Considerando a inconsistência de alguns diagnósticos de HPI (9), o potencial da MCR na redução de erros de diagnóstico $(14,15)$ e a falta de estudos para a caracterização de HPI com MCR, o objetivo do presente estudo foi caracterizar a HPI e correlacionar principais aspectos observados pela MCR com as características macroscópicas da HPI relacionada à acne. Dessa forma, o entendimento das características morfológicas da HPI 
tive medicines, and define the parameters to be evaluated in clinical efficacy studies.

In summary, studies describing the main epidermal characteristics of pigmentary lesions enable dermatologists to distinguish several lesions using an innovative and non-invasive technique in order to replace unnecessary biopsies for histopathological examination.

\section{Materials and Methods}

\section{Subject recruitment}

Twelve female Caucasian subjects with Fitzpatrick skin phototype III and IV, with PIH and active acne lesions on the malar region of the face, were recruited for a clinical study using imaging analysis. The age of the subjects ranged from 18 to 30 years, with a median of 22 years. It was recommended not to use topical medications and whitening cosmetics on the face for at least 30 days prior to the initation of the study. All subjects gave written informed consent prior to entering the study. The study was approved by the Ethics Committee of the Faculty of Pharmaceutical Sciences - University of Sao Paulo (CAAE: 65041616.9.0000.5403).

\section{Instrumental measuments - Reflectance Confocal Microscopy (RCM)}

PIH was evaluated by Reflectance Confocal Microscopy (Vivascope ${ }^{\circledR} 1500$; Lucid, United States). This technique uses a near infrared laser with a wavelength of $830 \mathrm{~nm}$ in order to obtain histological images in vivo (16). Since melanin is the main endogenous source of reflectance, it appears brighter in the images, causing this technique to be useful for the characterization of hyperchromias. The microscopic images were obtained with Vivastack ${ }^{\circledR}$, a system for obtaining multiple confocal images at successive depths ranging from 3 to 150 $\mu \mathrm{m}$ at a specific tissue site. All images were analyzed with the Image $\mathbf{J}^{\circledR}$ software (17). Macroscopic images of the tissue were obtained with VivaCam ${ }^{\circledR}$ (Lucid, USA) which captures both clinical and dermoscopic images with a high-precision optical system.

\section{Characterization of post-inflammatory hyperpigmentation by RCM}

In order to characterize the PIH, images were obtained é determinante para confirmar o diagnóstico, orientar o desenvolvimento de medicamentos eficazes e definir os parâmetros a serem avaliados nos estudos de eficácia clínica.

Em síntese, estudos descrevendo as principais características epidérmicas das lesões pigmentares permitem ao dermatologista distinguir várias lesões usando uma técnica inovadora e não invasiva, a fim de substituir biópsias desnecessárias para o exame histopatológico.

\section{Material e métodos}

\section{Recrutamento das participantes}

Doze participantes de pesquisa caucasianas do sexo feminino com fototipo III e IV de Fitzpatrick, com HPI e lesão acneica na região malar da face foram recrutadas para um estudo clínico usando análise de imagem. A idade das participantes de pesquisa variou de 18 a 30 anos e a mediana foi de 22 anos. Foi recomendado não usar medicações tópicas e cosméticos clareadores no rosto por pelo menos 30 dias antes do início do estudo. Todos os pacientes de pesquisa assinaram o termo de consentimento livre e esclarecido (TCLE) antes de entrar no estudo. O estudo foi aprovado pelo Comitê de Ética em Pesquisa Clínica da Faculdade de Ciências Farmacêuticas da Universidade de São Paulo (CAAE: 65041616.9.0000.5403).

\section{Medidas instrumentais - Microscopia Confocal de Refletância (MCR)}

A HPI foi avaliada por Microscopia Confocal de Reflectância (Vivascope ${ }^{\circledR}$ 1500; Lucid, Estados Unidos). Esta técnica utiliza um laser infravermelho próximo com um comprimento de onda de $830 \mathrm{~nm}$ para obter imagens histológicas in vivo (16). Como a melanina é a principal fonte endógena de refletância, ela aparece mais clara nas imagens, fazendo com que essa técnica seja útil para a caracterização de hipercromias. As imagens microscópicas foram obtidas com o Vivasta$\mathrm{ck}^{\circledR}$, um sistema para obtenção de múltiplas imagens confocais em profundidades sucessivas variando de 3 a $150 \mu \mathrm{m}$ em um local específico do tecido. Todas as imagens foram analisadas com o software Image $\mathbf{J}^{\circledR}$ (17). Imagens macroscópicas do tecido foram obtidas com VivaCam $^{\circledR}$ (Lucid, EUA), que captura imagens clínicas e dermatoscópicas com um sistema óptico de alta precisão.

\section{Caracterização da hiperpigmentação pós-inflamatória por $M C R$}

Para caracterizar a HPI, as imagens foram obtidas em 
in triplicate in the lesional and perilesional regions of the malar region of the volunteers and were used to quantitate the brightness of the basal cell layer, which is expressed as number of hyperreflective pixels, as well as DEJ thickness and the depth of the dermal papillae. The morphological and structural features of the DEJ were also analyzed.

\section{Statistical Analysis}

Statistical analysis was performed using GraphPad Prism $^{\circledR}$ 5. Absolute and relative frequencies of structural and morphological descriptors in the two populations were calculated. Analysis of variance was used to determine significant differences. A p-value $<0.05$ was considered to be significant.

\section{Results and Discussion}

PIH typically appears as asymptomatic macules, hyperchromic patches that may be symmetric or asymmetric, circumscribed or diffuse, depending on the distribution of the original inflammatory dermatosis (2), and mainly affects skin phototypes III, IV and V $(6,18)$.

Asymptomatic brown macules were demonstrated by the dermoscopy of a skin region affected by postinflammatory hyperpigmentation (Figure 1) and an increased pigmentation in lesional region was observed in images obtained by RCM through an increase of brightness of the basal cell layer (Figure 2). In addition, inflammatory cells were also observed in the epidermis as part of the inflammatory features of this lesion $(19,20)$. triplicata nas regiões lesional e perilesional da região malar das voluntárias e foram utilizadas para quantificar o brilho da camada basal, expressa em número de pixels hiperrefletivos, bem como DEJ espessura e te profundidade das papilas dérmicas. As características morfológicas e estruturais do DEJ também foram analisadas.

\section{Análise estatística}

A análise estatística foi realizada utilizando GraphPad Prism $^{\circledR}$ 5. As frequências absolutas e relativas dos descritores estruturais e morfológicos nas duas populações foram calculadas. Análise de variância foi usada para determinar diferenças significativas. $\mathrm{O}$ valor de $\mathrm{P}<0,05$ foi considerado significativo.

\section{Resultados e discussão}

A PIH tipicamente aparece como máculas assintomáticas, manchas hipercrômicas que podem ser simétricos ou assimétricos, circunscritos ou difusos, dependendo da distribuição da dermatose inflamatória original (2) que afeta principalmente a pele de fototipos III, IV e $\mathrm{V}$ $(6,18)$.

As máculas marrons assintomáticas foram demonstradas pela dermoscopia de uma região cutânea afetada por hiperpigmentação pós-inflamatória (Figura 1) e um aumento da pigmentação na região lesional foi observado em imagens microscópicas obtidas pelo MCR por meio de um aumento do brilho da camada basal (Figura 2). Além disso, células inflamatórias foram também observadas na epiderme como parte da característica da lesão inflamatória $(19,20)$.

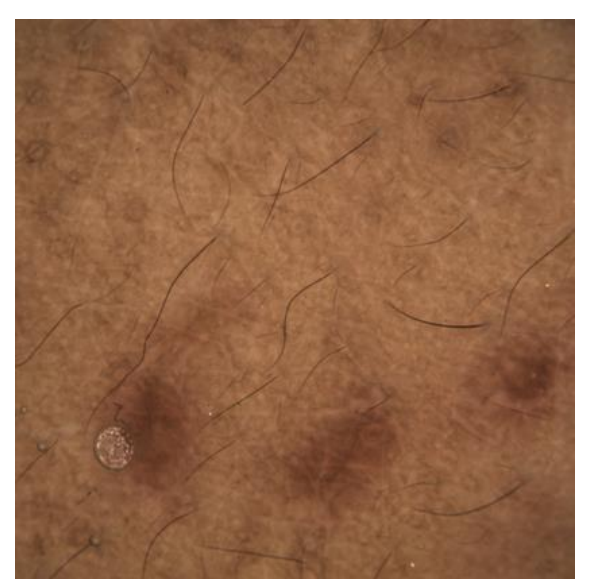

Figure 1/ Figura 1- Dermatoscopy of a skin region affected by post-inflammatory hyperpigmentation showing the principal macroscopic characteristic of PIH: asymptomatic brown macules (Scale 10x10 mm)/ Dermatoscopia de uma região cutânea afetada por hiperpigmentação pós-inflamatória, mostrando as principais características macroscópicas da HPI: máculas marrons assintomáticas (Escala 10x10 mm) 


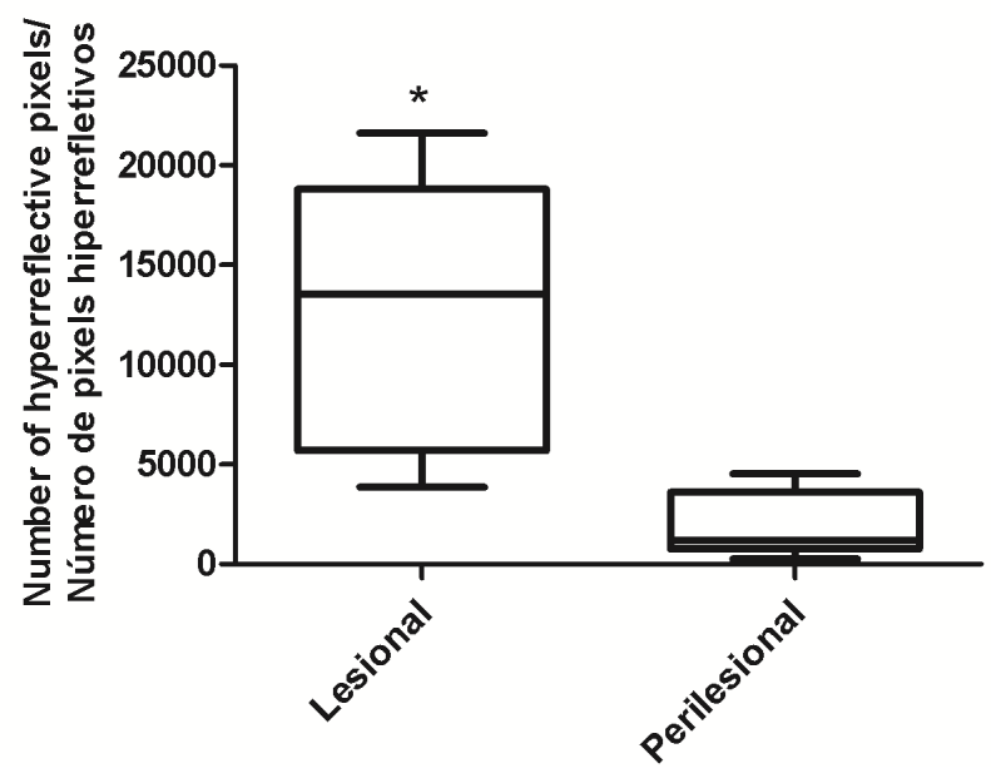

Figure 2/ Figura 2 - Comparison of epidermal pigmentation between lesional and perilesional regions. Since PIH is a type of hyperpigmentation, it is observed an increased pigmentation in lesional region when compared to perilesional region. (*Significant difference $-\mathrm{P}$ value $<0.05)$ / Comparação da pigmentação epidérmica entre as regiões lesional e perilesional. Como a PIH é um tipo de hiperpigmentação, observa-se aumento da pigmentação na região lesional quando comparada à região perilesional. (* Diferença significativa - valor de $\mathrm{P}<0,05$ )

According to previous studies, in PIH, the inflammatory infiltrate has small, homogeneously bright cells in a perivascular distribution or at epidermal levels (21). Morphological diferences between lesional and perilesional regions of PIH were observed by RCM, including increased size of dermal papillae, irregular shape of dermal papillae, loss of regular honeycomb pattern, presence of inflammatory infiltrate in epidermis and melanophages in papillary dermis (Table 1).

Regarding the morphological descriptors analyzed of DEJ, the main characteristic observed was the irregular shape of dermal papillae, which became elongated and larger, with a reduction of the number of dermal papillae per area (Figure 3) once there is disruption of basal keratinocytes in dermal hypermelanosis (6). This characteristic was observed in all subjects and not only in those with melanophages in the papillary dermis, suggesting that the disruption of the DEJ is not exclusively related to dermal hypermelanosis.

The findings in our study corroborate with other studies reported in scientific literature which described the presence of melanophages and a lymphocytic infiltrate in PIH (22), an inflammatory infiltrate which also appears in other inflammatory lesions such as spongiotic dermatitis and interface dermatitis (23) mainly involving the DEJ. Inflammatory cells can migrate into the epidermis as single elements or in a cluster, forming
De acordo com estudos anteriores, o infiltrado inflamatório tem células pequenas, homogeneamente brilhantes em uma distribuição perivascular ou em níveis epidérmicos (21).

Diferenças morfológicas entre as regiões lesionais e perilesionais da HPI foram observadas pela MCR, como aumento do tamanho das papilas dérmicas, forma irregular das papilas dérmicas, perda do padrão favo de mel regular, presença de infiltrado inflamatório na epiderme e melanófagos na derme papilar (Tabela 1).

Em relação aos parâmetros morfológicos analisados, a principal característica observada foi o formato irregular das papilas dérmicas, que são alongadas, maiores e com redução do número de papilas dérmicas por área (Figura 3), uma vez que há ruptura dos queratinócitos basais na hipermelanose dérmica (6). Essa característica foi observada em todos os voluntários e não apenas naqueles com melanófagos na derme papilar, sugerindo que a ruptura da JDE não está exclusivamente relacionada à hipermelanose dérmica.

Os achados no nosso estudo corroboram com outros estudos relatados na litertura científica, os quais descrevem a presença de melanófagos e infiltrado linfocitário na HPI (22), um infiltrado inflamatório também está presente em outras lesões inflamatórias, como dermatite espongiótica e dermatite de interface (23) envolvendo principalmente a JDE. As células inflamatórias 
Table 1/ Tabela 1 - Morphological descriptors observed by Reflectance Confocal Microscopy of Post-Inflammatory Hyperpigmentation / Descritores morfológicos observados por Microscopia Confocal de Reflectância de Hiperpigmentação Pós-Inflamatória

\begin{tabular}{lcc}
\hline Observed RCM Feature/ Parâmetro observado MCR & Lesional (n=12) & Perilesional (n=12) \\
\hline $\begin{array}{l}\text { Increased size of dermal papillae/ Aumento do tamanho } \\
\text { das papilas dérmicas }\end{array}$ & 12 & 2 \\
$\begin{array}{l}\text { Inflammatory infiltrate in epidermis/ Infiltrado } \\
\text { inflamatório na epiderme }\end{array}$ & 3 & 0 \\
$\begin{array}{l}\text { Irregular shape of dermal papillae/ Forma irregular das } \\
\text { papilas dérmicas }\end{array}$ & 12 & 4 \\
$\begin{array}{l}\text { Loss of regular honeycomb pattern/ Perda de padrão } \\
\text { regular de favo de mel } \\
\text { Melanophages in papillary dermis/ Melanófagos na derme } \\
\text { papilar }\end{array}$ & 8 & 2 \\
\hline
\end{tabular}

intra-epidermal vesicles (23). In PIH they were mainly observed as single cells concentrated in the hyperpigmented region.

In addition, PIH may present with epidermal, dermal, or mixed melanocytic involvement (19). Melanophages present as large, diffuse, and bright cells with poorly defined cytoplasmic borders (20) where melanin can be accumulated. When they accumulate in the upper dermis, there is destruction of the basal keratinocytes $(4,6)$, making the lesion more persistent (2).

Another important characteristic observed in the PIH is the reduction of the thickness of the JDE in relation to the perilesional region (Figure 4), which demonstrates the flattening of this layer. Despite the reduction of JDE thickening, there was no significant difference in epidermal thickness between lesional and perilesional regions (Figure 5).

Although recent in the dermatological area, the application of RCM in the assessment of pigmentation disorders has been expand to describe both pigmentary alterations, hyper and hypopigmentation, as well as pigmented cutaneous tumors $(12,20)$. Recent studies have demonstrated that the results obtained with the application of RCM to dermatology can improve diagnostic accuracy, with some confocal criteria showing high sensitivity and specificity (21).

The results obtained are in accordance with those previously reported in the literature $(2,7,22)$, demonstrating the correlation between the analysis of PIH obtained by $\mathrm{RCM}$ and the histopathological exams. podem migrar para a epiderme como elementos únicos ou aglomerados formando vesículas intraepidérmicas (23). Na HPI eles foram observados principalmente como células únicas concentradas na região hiperpigmentada.

Além disso, na HPI pode ocorrer o envolvimento melanocítico na epiderme, derme ou em ambas as camadas (19). Melanófagos apresentam-se como células largas, difusas e brilhantes com bordas citoplasmáticas pobremente definidas (20) onde a melanina pode estar acumulada. Quando estes se acumulam na derme superior, há destruição de queratinócitos basais $(4,6)$, tornando a lesão mais persistente (2).

Outra característica importante observada na HPI é a redução da espessura da JDE em relação à região perilesional (Figura 4), que demonstra o achatamento desta camada. Apesar da redução do espessamento da JDE, não houve diferença significativa na espessura da epiderme entre as regiões lesional e perilesional (Figura $5)$.

Embora recente na área dermatológica, a aplicação da MCR na avaliação de distúrbios da pigmentação tem sido ampliada para descrever ambas alterações pigmentares, hiper e hipopigmentação, bem como tumores cutâneos pigmentados $(12,20)$. Estudos recentes demonstraram que os resultados obtidos com a aplicação da MCR na dermatologia podem melhorar a precisão diagnóstica, com alguns parâmetros da MCR demonstrando alta sensibilidade e especificidade (21).

Os resultados obtidos estão de acordo com os relata- 
In histopathological exams of PIH is possible to identify the melanin location with Fontana-Masson silver stain applied to the tissue, and also, to observe the inflammatory infiltrate and basal cell vacuolation using Alcian blue stain (7). All these analysis can be evaluated in microscopic images generated by RCM through a non-invasive method and without the necessity of tissue coloration. Additionally, it is possible to determine another important PIH morphological characteristics as described above. Finally, the results in this study demonstrated that RCM is an accurate method to objectively support the diagnosis of PIH.
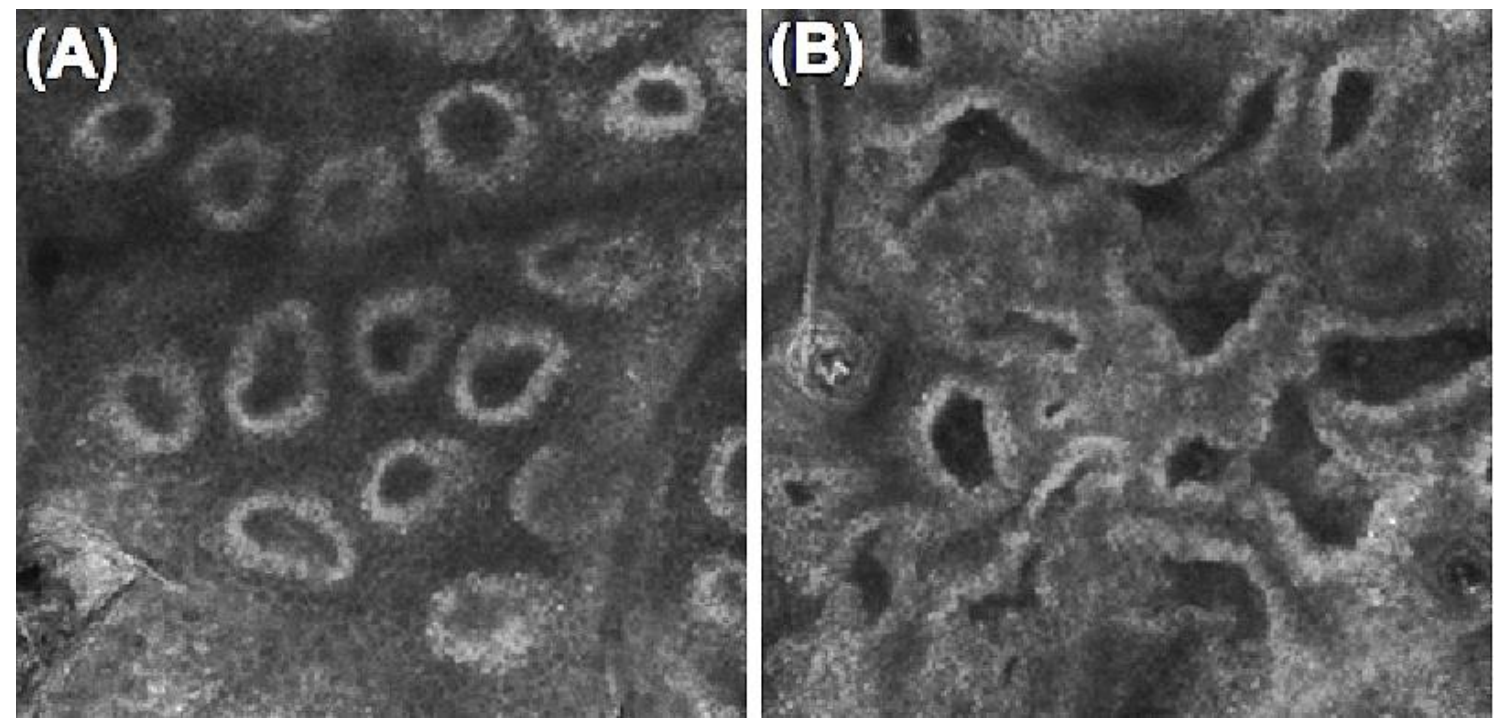

Figure 3/ Figura 3 - (A) Dermal-epidermal junction of perilesional region. It is possible to observe regular shapped (round) dermal-pappilas with well-defined and whitish borders and an totally dark space between them representing an regular pigmentation (Scale $500 \times 500 \mu \mathrm{m}$ ); (B) Dermal-epidermal junction of lesional region. It is possible to observe the irregular shape and increased size of dermal papillas, loss in their contour definition, more pigmented epidermis (space between the papillas) due to the higher amount and irregular concentration of melamin when compared to perilesional region (Scale $500 \times 500$ $\mu \mathrm{m}) /(\mathrm{A})$ Junção dermoepidérmica da região perilesional. É possível observar papilas dérmicas regulares (redondas) com bordas bem definidas e esbranquiçadas e um espaço totalmente escuro entre elas, representando uma pigmentação regular (Escala 500 x500 $\mu \mathrm{m}$ ); (B) Junção dermoepidérmica da região lesional. E possível observar a forma irregular e o aumento do tamanho das papilas dérmicas, perda na definição do contorno, epiderme mais pigmentada (espaço entre as papilas), pois há maior quantidade de melanina e concentração irregular de melanina quando comparada à região perilesional (Escala 500 $\mathrm{x} 500 \mu \mathrm{m})$. 


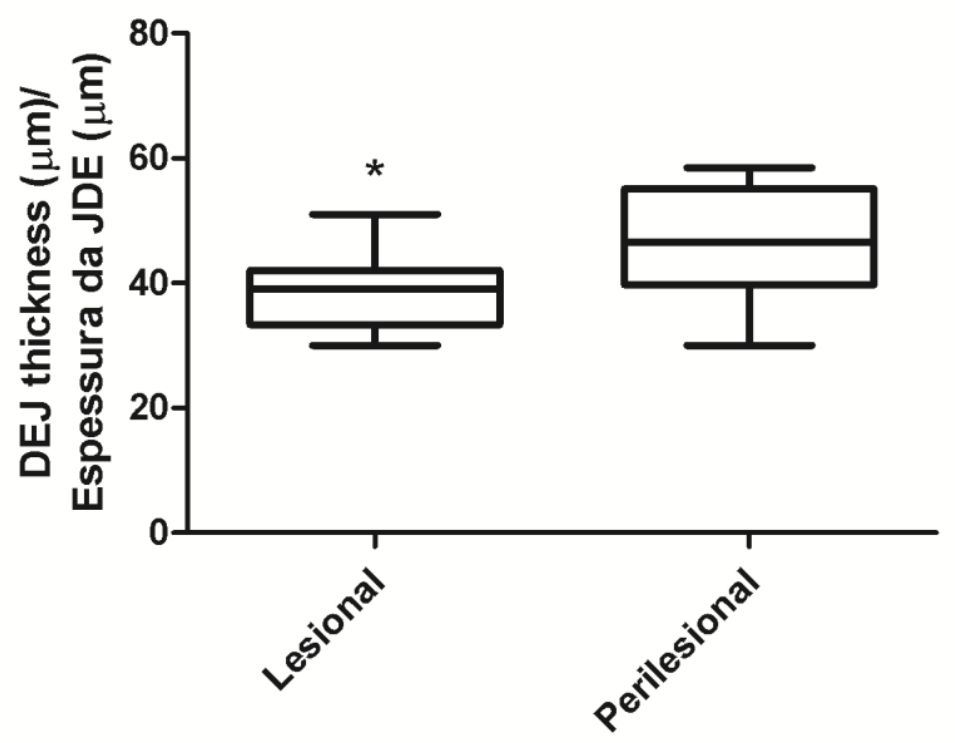

Figure 4/ Figura 4 - Comparison of dermal-epidermal junction (DEJ) thickness between the lesional and perilesional regions (*Significant difference $-p$ value $<0.05$ )/ Comparação da espessura da junção dermoepidérmica (JDE) entre as regiões lesional e perilesional (* Diferença significativa - valor de $\mathrm{P}<0,05$ )

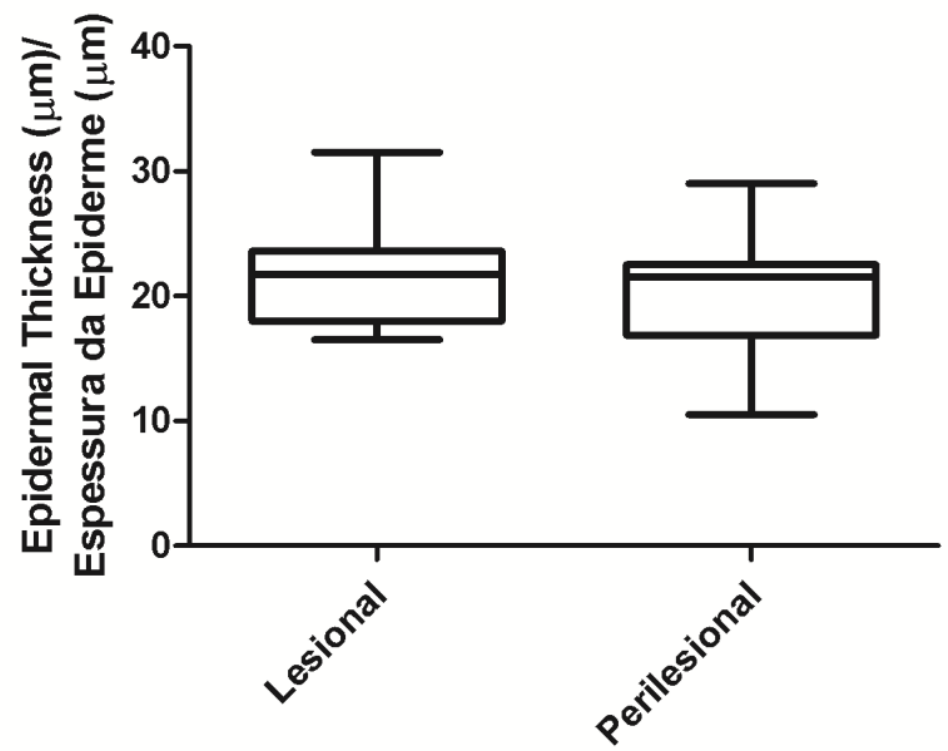

Figure 5/ Figura 5 - Comparison of epidermal thickness between the lesional and perilesional regions showing no significant difference between the two regions studied/ Comparação da espessura epidérmica entre as regiões lesional e perilesional sem diferença significativa entre as duas regiões estudadas. 


\section{Conclusion}

The present study describes the features of PIH analyzed by RCM, an advanced imaging technique that can replace the histological biopsy and objectively and non-invasively assist in the diagnosis of PIH. In addition, the images obtained from the RCM support the general clinical findings of hyperpigmentation of the skin observed by the researchers, since a correlation was observed between the main aspects analyzed by the RCM and the macroscopic characteristics of PIH related to acne.

\section{Acknowledgements}

The authors wish to thank FAPESP - Fundação de Amparo à Pesquisa do Estado de São Paulo (proc2014/26988-5) and CNPq - Conselho Nacional de Desenvolvimento Científico e Tecnológico (proc $n^{0} 308745 / 2015-9$ ) for financial support.

\section{Conflict of Interest}

The authors declare that there is no financial or personal relationship that can be understood as representing a potential conflict of interest.

\section{Conclusão}

O presente estudo descreve as características da HPI analisada pelo MCR e pode auxiliar objetivamente e de modo não invasivo no diagnóstico da HPI, sendo um técnica avançada de imagem que pode substituir a biópsia histológica. Além disso, as imagens obtidas da MCR suportam os achados clínicos gerais de hiperpigmentação da pele observados pelos pesquisadores, uma vez que foi observada correlação entre os principais aspectos analisados pela MCR e as características macroscópicas da HPI relacionada à acne.

\section{Agradecimentos}

Os autores gostariam de agradecer à FAPESP - Fundação de Amparo à Pesquisa do Estado de São Paulo ((proc- 2014/26988-5) e o CNPq - Conselho Nacional de Desenvolvimento Científico e Tecnológico (proc $\left.\mathrm{n}^{\mathrm{o}} 308745 / 2015-9\right)$ pelo apoio financeiro.

\section{Conflito de interesses}

Os autores declaram que não há relação financeira ou pessoal que possa ser entendida como a representar um potencial conflito de interesses. 


\section{References/Referências}

(1) Abad-Casintahan F, Chow SKW, Goh CL et al. Frequency and characteristics of acne-related post-inflammatory hyperpigmentation. J Dermatol. 2016; 43:826-8.

(2) Callender VD, St Surin-Lord S, Davis EC et al. Postinflammatory Hyperpigmentation Etiologic and Therapeutic Considerations. Am J Clin Dermatol $2011 ; 12: 87-99$.

(3) Ho SG, Yeung CK, Chan NP et al. A Retrospective Analysis of the Management of Acne Post-Inflammatory Hyperpigmentation Using Topical Treatment, Laser Treatment, or Combination Topical and Laser Treatments in Oriental Patients. Lasers Surg Med 2011; 43:1-7.

(4) Zawar VP, Agarwal M, Vasudevan B. Treatment of Postinflammatory Pigmentation Due to Acne with Q-Switched Neodymium -Doped Yttrium Aluminium Garnet in 78 Indian Cases. J Cutan Aesthet Surg 2015; 8:222-6.

(5) Oram Y, Akkayam AD. Refractory Postinflammatory Hyperpigmentation Treated Fractional CO2 Laser. J Clin Aesthet Dermatol 2014; 3:42-4.

(6) Yadalla HKK, Aradhya S. Post Acne Hyperpigmentation: A Brief Review. Our Dermatol Online 2011; 2:230-1.

(7) Lacz NL, Vafaie J, Kihiczak N et al. Postinflammatory hyperpigmentation: a common but troubling condition. Int J Dermatol 2004; 43:362-5.

(8) Hofmann-Wellenhof R, Pellacani G, Malvehy J et al. Pigmentary Skin Disorders. In: Hofmann-Wellenhof R, Pellacani G, Malvehy J et al. editors. Reflectance Confocal Microscopy for Skin Diseases. 1st ed. Heidelberg:Springer-Verlag; 2012. p.401-413.

(9) Goh CL, Abad-Casintahan F, Chow SKW et al. Evaluating acne-related post-inflammatory hyperpigmentation is a challenge even amongst experts. J Dermatol 2014; 41:1106-8.

(10) Martini APM, Mercurio DG, Maia Campos PMBG. Assessment of skin pigmentation by confocal microscopy: Influence of solar exposure and protection habits on cutaneous hyperchromias. J Cosmet Dermatol 2017; 16:364-9.

(11) Lagarrigue SG, George J, Questel E et al. In vivo quantification of epidermis pigmentation and dermis papilla density with reflectance confocal microscopy: variations with age and skin phototype. Exp Dermatol 2012; 21:281-6.

(12) Kang HY, Bahadoran P, Ortonne JP. Reflectance confocal microscopy for pigmentary disorders. Exp Dermatol 2010; 19:233-9.

(13) Rajadhyaksha M, Grossman M, Esterowitz D et al. In vivo confocal scanning laser microscopy of human skin: melanin provides strong contrast. J Invest Dermatol 1995; 104:946-52.

(14) Wurm E, Pellacani G, Longo C et al. The value of reflectance confocal microscopy in diagnosis of flat pigmented facial lesions: a prospective study. J Eur Acad Dermatol Venereol 2017; 31:1349-54.

(15) Guitera P, Pellacani G, Longo C et al. In vivo reflectance confocal microscopy enhances secondary evaluation of melanocytic lesions. J Invest Dermatol $2009 ; 129: 131-8$.

(16) Sauermann K, Clemann S, Jaspers S et al. Age related changes of human skin investigated with histometric measurements by confocal laser scanning microscopy in vivo. Skin Res Technol 2002; 8:52-6.

(17) Longo C, Caspari A, Beretti F et al. Skin aging: in vivo microscopy assessment of epidermal and dermal changes by means on confocal microscopy. J Am Acad Dermatol 2013; 68:73-82.

(18) Wolff K, Johnson RA, Suurmond D. Hiperpigmentações. In: Wolff K, Johnson RA, Suurmond D editors. Dermatologia: Atlas e texto. 5th ed. São Paulo:McGraw-Hill Interamericana do Brasil; 2006. p.350-353.

(19) Adalatkhah H, Bazargani HS. The association between melasma and postinflammatory hyperpigmentation in acne patients. Iran Red Crescent Med J $2013 ; 15: 400-3$.

(20) Busam KJ, Charles C, Lee G et al. Morphologic features of melanocytes, pigmented keratinocytes, and melanophages by in vivo confocal scanning laser microscopy. Mod Pathol 2001; 14:862-8.

(21) Samhaber KT, Buhl T, Brauns B et al. Morphologic criteria of vesiculobullous skin disorders by in vivo reflectance confocal microscopy. J Dtsch Dermatol Ges 2016; 14:797-805.

(22) Pollefliet C, Corstjens H, Gonzalez S et al. Morphological characterization of solar lentigines by in vivo reflectance confocal microscopy: a longitudinal approach. Int J Cosm Sci 2013; 35:149-55.

(23) Agozzino M, Gonzalez S, Ardigò M. Reflectance Confocal Microscopy for Inflammatory Skin Diseases. Actas Dermosifiliogr 2016; 107:631-9.

(24) Isedeh P, Kohli I, Al-Jamal M et al. An in vivo model for post-inflammatory hyperpigmentation: an analysis of histological, spectroscopic, colorimetric and clinical traits. Br J Dermatol 2015; 174:862-8. 